\title{
8. PAGIOPHYLLUM MARITIMUM SP. NOV., AND DESCRIPTIVE NOTES ON THE DISPERSED CUTICLES FROM LEG 40, SITE 361
}

\author{
John T. Brown, Bernard Price Institute for Palaeontological Research, \\ University of Witwatersrand, Johannesburg 2001, R.S.A
}

\begin{abstract}
Separate cuticle fragments (209) from Cores 30, 31, 36, and 45 have been analyzed and nine different taxa of gymnospermous leaves identified. Only one of these can be assigned with certainty to a known genus of conifer (Pagiophyllum). The remaining eight taxa are only described but not given formal taxonomic status. Three most certainly belong to the Cycadeoidaceae, the remaining five can only be ascribed to the gymnosperms in the broadest sense.
\end{abstract}

\section{INTRODUCTION}

This report deals with the description and possible interpretations of the cutinized remains of isolated leaves and leafy stems from Cores $30,31,36$, and 45 recovered from drilling at Site 361. At these levels large numbers of small pieces of wood were also recovered, but unfortunately these woods were too poorly preserved for systematic study. The cuticle remains from these levels represent at least nine different taxa of gymnospermous leaves, only one of which can be attributed to a known fossil conifer genus. The most abundant types are six different gymnosperms; one, represented by both leafy stems and dispersed leaves, is assigned to Pagiophyllum, a well known Mesozoic genus. The remaining five cuticle types are known only from isolated leaves, and are thus not assignable at the generic level. All six types are, however, distinct enough to indicate the diversity of gymnosperms which must have grown at or very near the locality of Site 361 .

Three additional types of cuticle fragments, which can with some certainty be assigned to the family Cycadeoidaceae, are also described. As with the conifers and other gymnosperms, the cuticles are fragmentary and cannot be compared to known genera. They are quite distinctive from one another in their epidermal morphology and again give some evidence of the diversity of plants which grew near the site. An attempt has also been made to relate these fossils to those known from other Upper Jurassic or Lower Cretaceous plants of the Southern Hemisphere (Figure $1)$.

\section{MATERIALS AND METHODS}

The material for this study was macerated to release the wood and cuticle from the rock matrix. Individual pieces of cuticle were treated in Schultze's solution for one and a half to three hours, bleached in $10 \%$ commercial bleach, dehydrated, and mounted in Depex. A total of 209 cuticle fragments were prepared, and these are located in the collections of the Bernard Price Institute for Palaeontological Research at the University of Witwatersrand, Johannesburg. Types and figured specimens are catalogued with B.P.I.(Pal.) PB. type numbers, the remainder under accession number 274-1 to 8 .

\section{SYSTEMATIC PALEOBOTANY}

\section{CONIFEROPHYTA}

PAGIOPHYLLUM

Pagiophyllum maritimum sp. nov. (Plate 1, Figures 15-19; Text-Figures 2-5)

Diagnosis: Vegetative conifer branches with sessile, lanceolate helically arranged leaves, free tip longer than the base. Margin microscopically scarious. Leaves falcate, convex.

Cuticle: Thick, square to long rectangular epidermal cells with thick straight walls forming rows between files of stomata; stomata haplocheilic, circular near apex, more elliptical toward base of leaf, generally in files; may have adjacent, but never shared subsidiary

PALEOGEOGRAPHY OF SOME UPPER MESOZOIC FLORAS

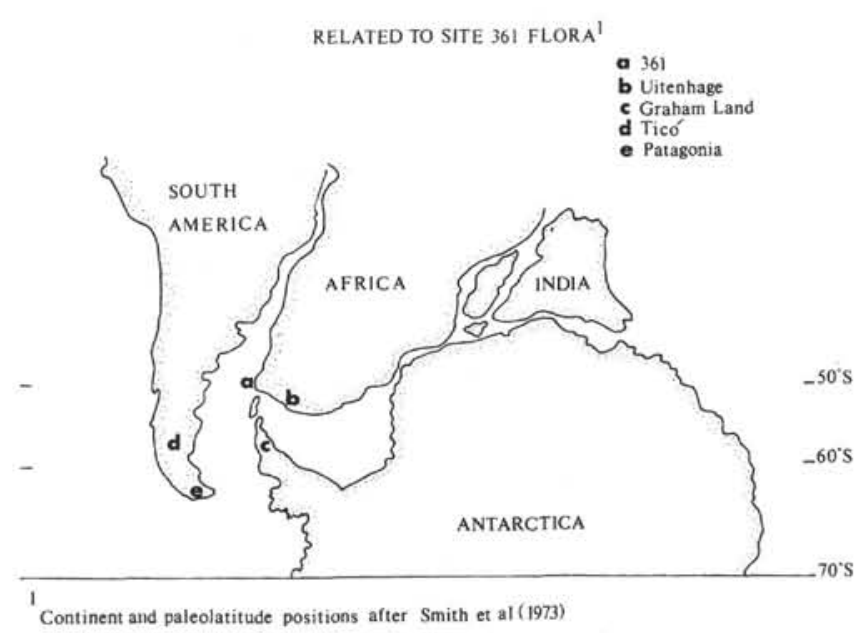

Figure 1. Medial Cretaceous continent and paleolatitude location of Site 361 flora and some floras of similar age from South Africa, South America, and Antarctica. 
cells; epidermal cells in stomatal files polygonal to square, files of stomata regular toward apex of leaf; subsidiary cells straight-walled, 4-7 usually 5 either polygonal or elongate, tangential to rim of stomatal pore; guard cells sunken, pore cylindrical; subsidiary cells form a slight cutinized ring defining the stomatal pore; marginal cells of leaf elongate form row oblique to long axis of leaf.

Holotype: B.P.I. (Pal.) P. B. 125.

Derivation of specific epithet: from the Latin maritimus meaning "growing by the sea."

Discussion: This conifer forms the bulk of the recovered remains from the cores and is clearly allied by leaf morphology with Pagiophyllum. The microscopic characters of the leaf cuticle are also within the range of those reported for this genus (Kendall, 1948; Adams, 1951; Ash, 1970).

Generically Pagiophyllum is distinguished from Brachyphyllum by the ratio of free leaf tip length to length of basal cushion (Kendall, 1948). The fossils described here all fall within the range of Pagiophyllum where the length of free leaf apex considerably exceeds that of the basal cushion. Due to the flattening of the specimens, an estimate of the phyllotaxic spiral is impossible.

The leaves are quite small, and, since two of the four stem specimens seem to be terminal segments, the mature leaf may have exceeded the average measured value for these attached leaves. Isolated leaves assigned to this species measured an average of 3.0 $\mathrm{mm}$ in length by $1.5 \mathrm{~mm}$ in width, and this value is probably close to the average for the entire plant. It is only attached leaves which clearly show the falcate and convex nature of the living leaf (Figure 5; Plate 1, Figure 15). The isolated leaves are usually quite flattened and frequently folded. As reconstructed, the leaf gives a biconvex section with a slight lateral margin formed by the elongate marginal cells where the upper and lower surfaces meet (Figure 5).

Microscopically the leaf margin is seen to be composed of a single row of cylindrical or long conical cells with their long axes oblique to or at the apex parallel with the long axis of the leaf (Figure 4; Plate 1, Figure 16). The distribution of the marginal cells varies. In some it is confined to the distal one-third of the leaf; in others it continues to very near the base. These cells are quite thick, cutinized at the base, but the cutinized portion of the walls thins noticeably toward their apex. Usually they are broken off at the outermost margin, but some cells were measured to be $90 \mu \mathrm{m}$ long by $10-20 \mu \mathrm{m}$ wide. At the leaf apex, these cells may form a distinct cluster giving a microscopically apiculate tip to each leaf (Plate 1, Figure 16). Ordinary epidermal cells between the files of stomata on either the ab- or adaxial surface tend to be square to rectangular, up to 5 times as long as broad, and oriented in longitudinal rows. These cells generally have fairly thick walls up to $7-8 \mu \mathrm{m}$, which occasionally have well-defined "pits" between adjacent cells (Plate 1, Figures 15-19). The anticlinal walls are straight and smooth, other than the "pits." Epidermal cells within the stomatal rows are mostly polygonal to nearly square, but only rarely elongate. None of the epidermal cells have ornamentation occurring on the periclinal walls.

The stomata are arranged in single files near the base and middle of the leaf. On the upper surface, however, the stomata near the leaf apex may have a scattered distribution (Plate 1, Figures 17, 19). Within stomatal files, occasional pairs of stomata may be separated by only one epidermal cell, but they never share a common subsidiary cell; only rarely are the subsidiary cells ever in contact between adjacent stomata (Plate 1, Figure 17). The stomatal apparatus, including subsidiary cells, is elliptical, obviously eccentric near the base but less so distally (Plate 1, Figure 19). With the complete ring of subsidiary cells, the stomatal apparatus measures about $85 \mu \mathrm{m}$ along the long axis, one-half to one-third that across the shorter axis in more eccentric examples (Figure 2; Plate 1, Figures 18, 19). In elongate stomata, the longest axis is more commonly parallel the long axis of the leaf but occasionally obliquely oriented (Plate 1, Figure 19). The subsidiary cell ring is composed of as few as four or as many as seven cells, either polygonal or elongate tangential to the pore (Figure 2; Plate 1, Figure 18). This subsidiary cell ring forms a continuous series, unbroken by polar cells, with a prominent rim surrounding the pore. The rim is cutinized somewhat more heavily than the other walls of the subsidiary cells and is continuous with the lateral walls which line the cylindrical pore cavity (Figures 2,3 ). The guard cells are thinly cutinized, with the pore irregularly oriented (Plate 1, Figure 17). Distortion of the pore cavity by pressure may give the impression that the subsidiary cells partially obscure the outer opening. In cross section, however, the cavity seems cylindrical (Figure 3). Average measured diameter of the pore cavity is $35 \mu \mathrm{m}$.
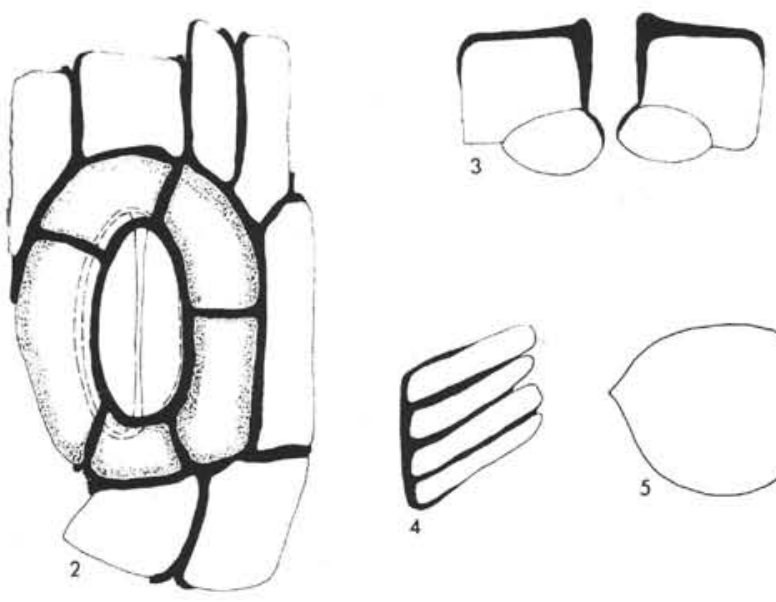

Figures 2-5. Pagiophyllum maritimum sp. nov. (2) Stomata with subsidiary cells $\times 475$ Holotype PB125; (3) Diagrammatic section of stomata in Figure 2, $X 475$, (4) Marginal cells of leaf of PB125, X 160;(5) Reconstruction of transverse section of the leaf of PB125, $\times 16$.

That these specimens are best placed in the genus Pagiophyllum is evident from their overall morphology. The free leaf apices are prominently longer than the leaf base, and their cuticular morphology is quite similar to the other species of the genus (Kendall, 1948). Pagiophyllum maritimum, however, differs from the other known species in several ways. The leaf size of even the largest leaves of $P$. maritimum is significantly less than any other species except $P$. simpsonii, $P$. masculosum, and $P$. gracillimum, from which species it differs in cuticular morphology. P. simpsonii of the Triassic has scattered stomata only rarely in rows, and papillae occur on the subsidiary cells and ordinary epidermal cells (Ash, 1970). $P$. masculosum Kendall, a small leaved, superficially similar species from the Yorkshire Jurassic, has several features which differentiate it from Pagiophyllum maritimum. P. masculosum is hypostomatic, has encircling cells which overlap the subsidiary cells, and a small papillus on each epidermal cell; whereas, P. maritimum is amphistomatic, has only flat encircling cells, and no papillae are present (Kendall, 1948). The third small leaved species, $P$. gracillimum Adams, also from the Jurassic of Yorkshire, is the most similar to P. maritimum, but it has very different smaller solid trichomes which are scattered along the leaf margin (Adams, 1951).

\section{CONIFERALES}

Family incertae sedis

\section{Papillate Conifer Type A}

(Text Figures 6, 7)

Description: This conifer may only represent an extreme of the Pagiophyllum maritimum type where the subsidiary cells, which normally form a rim around the pore, have gone to the extreme of enlargement creating a rim dissected into solid papillae which may overarch the pore. The general features and size of the stomata are otherwise quite similar.

The two types do differ in that this cuticle has more regular files of stomata; the leaf was larger, $3 \mathrm{~mm} \times 3 \mathrm{~mm}$, with only one margin; and it has the very prominently developed cutin rim which may reach $25 \mu \mathrm{m}$ in thickness, as opposed to 4 to $6 \mu \mathrm{m}$ for Pagiophyllum (Figures $6,7)$. A second specimen of this type has extraordinarily large stomata up to $120 \mu \mathrm{m} \times 108 \mu \mathrm{m}$ with a pore size of $50 \mu \mathrm{m} \times 40 \mu \mathrm{m}$ and, where the margin is preserved, has elongate cells with thick walls which parallel the leaf margin and do not form a frill.

\section{Papillate Conifer Type B}

(Plate 2, Figure 22; Text-Figure 8)

Description: This conifer is only known from a single broadly lanceolate leaf with a prominent acuminate apex. The leaf measures $3.5 \mathrm{~mm}$ long by $2.0 \mathrm{~mm}$ at widest, near mid point. The apex has a frill of elongate cells. Generally the stomata form files near the leaf base, 

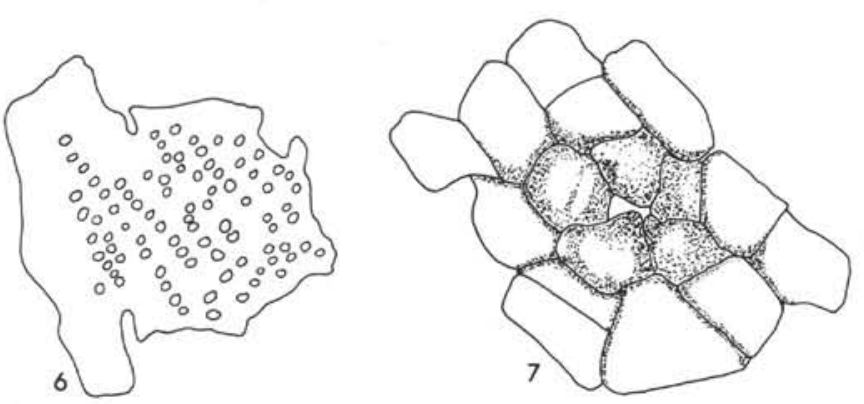

Figures 6,7. Conifer cuticle, specimens PB133. (6) Stomatal rows $\times 9$, (7) Stoma with papillate subsidiary cells, $\times 300$.

but these files become less well defined near the apex (Plate 2, Figure 22). The stomata are elliptical and tend to be elongate parallel the larger leaf axis. There are 4 to 6 subsidiary cells, usually in an incomplete ring (Figure 8; Plate 2, Figure 22). The lateral subsidiary cells are elongate tangential to the pore, but the terminal subsidiary cells resemble ordinary epidermal cells. The non-stomatal epidermal cells are square or polygonal near the leaf base, and along the median line near the leaf base each has one or sometimes two relatively large papillae on its surface (Plate 2, Figure 22). Nearer the apex the epidermal cells become more regularly rectangular with thick straight walls and tend to form short rows. Near the apex, papillae are quite rare.

\section{Papillate Conifer Type C}

\section{(Plate 2, Figure 21; Text-Figure 9)}

Description: Several fragments of leaves with epidermal cells which have cutinized papillae are included in this group. The stomata are nearly circular and scattered with 4 to 6 subsidiary cells, which are scarcely differentiated from the ordinary epidermal cells. Almost every epidermal or subsidiary cell has a near-centrally-located solid papillus (Figure 9; Plate 2, Figure 21). The epidermal cells are mostly polygonal and may occur in short but distinct rows. Their walls are thick and straight with some tendency to fill in at the corners where several cells join (Figure 9). The epidermal papillae measure about 8 $\mu \mathrm{m}$ in diameter and are only slightly raised above the cell surface (Figure 9; Plate 2, Figure 21). Stomata average $70 \mu \mathrm{m} \times 60 \mu \mathrm{m}$ with sunken, thinly cutinized guard cells. The subsidiary cells, if differentiated, are elongate tangential to the stomatal pore. The subsidiary cells do not form a prominent cutin rim round the stomatal pore.

\section{GYMNOSPERMS INCERTAE SEDIS}

Gymnosperm Cuticle Type A

(Plate 2, Figure 23; Text-Figure 10)

Description: A single leaf of this gymnospermous type has been found. The leaf shape is lanceolate with an extended apex. The

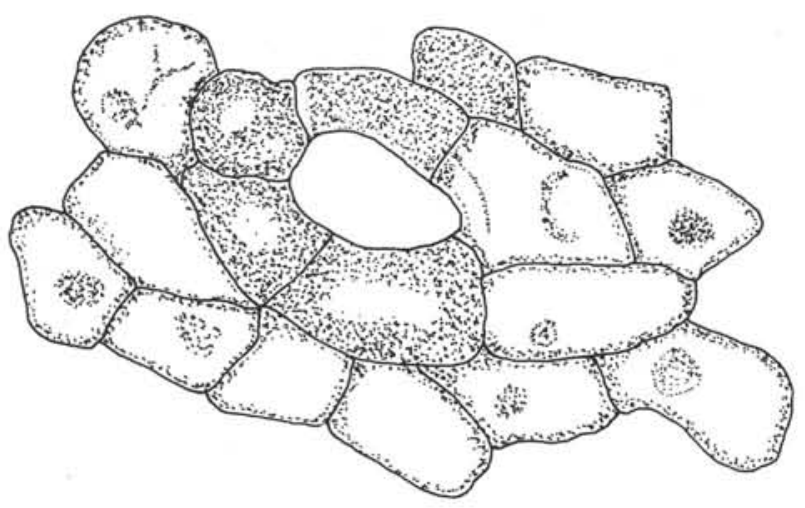

Figure 8. Stoma of papillate conifer cuticle with thickened subsidiary cells, speciment PB132, $\times 450$.

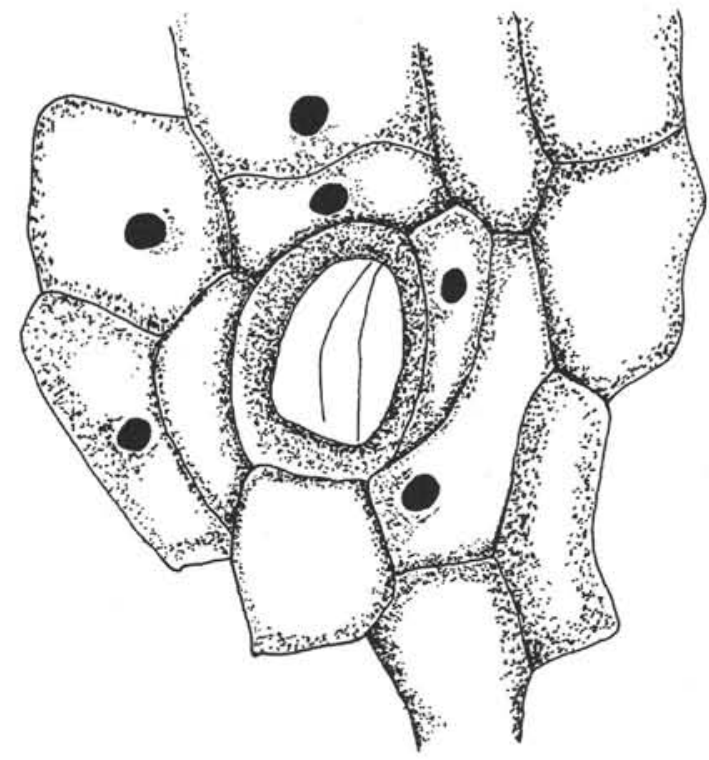

Figure 9. Stoma and subsidiary cells of conifer, solid dots represent papillae, specimen $P B$ $129, \times 375$.

stomata form distinct files with an occasional misplaced stoma between files (Plate 2, Figure 23). The stomata are elongate-elliptical oriented with their long axis parallel the longer leaf axis. Within the stomatal files, stomata may be widely spaced or share subsıdiary cells (Plate 2, Figure 23). The stomata are most distinctive. Each is surrounded by a ring of subsidiary cells, 6 to 8 in number and an outer ring of specialized encircling cells (Figure 10). Each subsidiary cell bears a large hollow papillus which overhangs the stomatal pore. Those of the outer encircling ring almost completely overhang those of the subsidiary cell row closer to the stomatal pore. The outer papillae are thick-walled and dark colored, while the inner row of papillae are shorter with a thin clear cuticle (Figure 10). Guard cells have not been observed. The entire stomatal apparatus measures 95

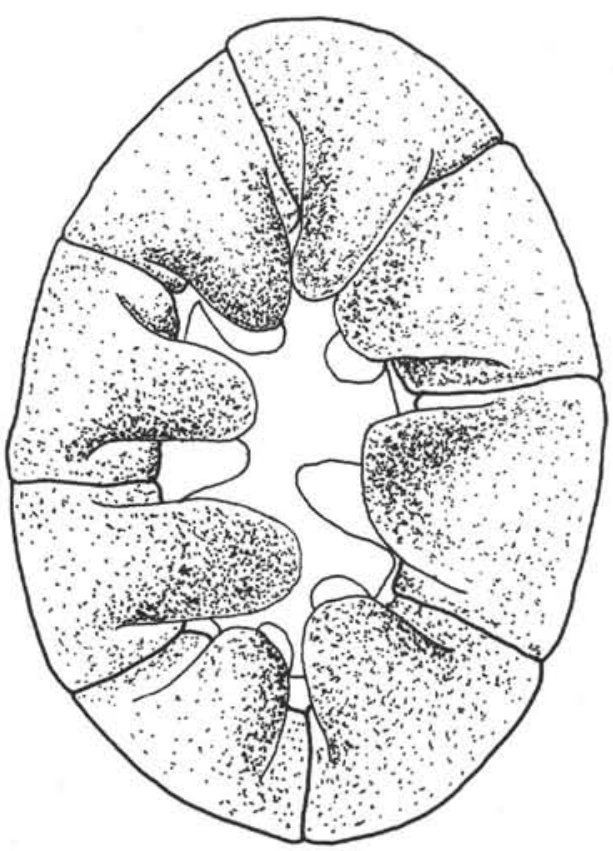

Figure 10. Stoma with double ring of encircling cells, specimen PB130, $\mathrm{X}$ 800 . 
$\mu \mathrm{m}-115 \mu \mathrm{m}$ in length by $60 \mu \mathrm{m}-75 \mu \mathrm{m}$ in width. No other epidermal cells bear papillae. The ordinary non-stomatal epidermal cells are rectangular or polygonal with thick straight walls (Plate 2, Figure 23).

\section{Gymnosperm Cuticle Type B}

(Plate 1, Figure 20; Text-Figure 11)

Description: A small leaf fragment with precise rows of stomata (Plate I, Figure 20). The individual stomata are elongate elliptical in outline with their pores oriented transverse to the long axis of the leaf (Figure 11). The stomata which range in size from $75 \mu \mathrm{m}$ to $95 \mu \mathrm{m}$ long by about $55 \mu \mathrm{m}$ to $60 \mu \mathrm{m}$ in width are arranged in files directiy adjacent to each other. Usually only one or two rows of smal polygonal cells separate the subsidiary cells of neighboring stomata (Plate 1, Figure 20). The stomata are sunken, and the entire file of stomata is defined by rows of marginal cells with large hollow papillae which may project over the stomatal files (Figure 11: Plate 1, Figure 20). Epidermal cells between files of stomata are square, occur in rows, and have thick straight walls (Plate 1, Figure 20). The surface of the epidermal cells, especially those with papillae, has an overall granular appearance (Plate 1, Figure 20).

There are some slight resemblances between this cuticle type and the pteridosperm Ruflorinia sierra Archangelsky from the Ticó Flora of Argentina (Archangelsky, 1966). The differences and the incomplete nature of the Site 361 material, however, make strict comparison futile.

\section{CYCADEOIDACEAE}

\section{GENERA INCERTAE SEDIS}

Cycadeoid Type A

(Plate 2, Figure 25; Text-Figure 12)

Description: This type is represented by only one fragment, about $2.0 \mathrm{~mm}$ wide, of a leaflet with both its apex and base missing. The fragment consists of only one cuticle, probably the lower. The cuticle is thin, with the pattern made up of polygonal to rectangular epidermal cells outlined by very prominently sinuous anticlinal walls (Plate 2, Figure 25). These epidermal cells measure about $65 \mu \mathrm{m}-70$ $\mu \mathrm{m}$ wide. The stomata are evenly distributed across the surface and tend to occur in short rows parallel the margins (Plate 2, Figure 25). The aperture of the guard cells is oriented transversely and averages $30 \mu \mathrm{m}$ in length (Figure 12; Plate 2, Figure 25). The guard cells are not much sunken below the surface of the epidermis and have a fairly thickly cutinized surface facing the pore (Figure 12). Overall, the stomata with its subsidiary cells is circular to elliptical in shape, measuring $70 \mu \mathrm{m}$ by $60 \mu \mathrm{m}$. The subsidiary cells are semicircular with

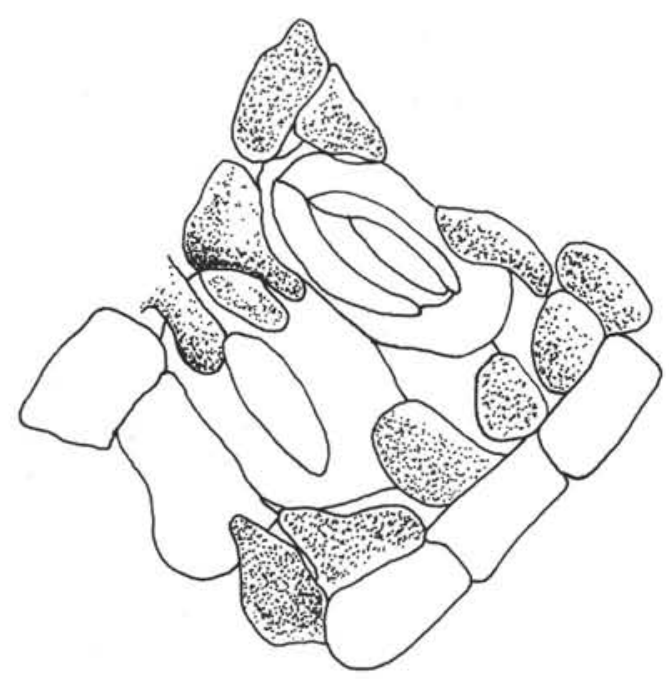

Figure 11. Two stomata of one row with well developed papillae, specimen PB131, $\times 325$.

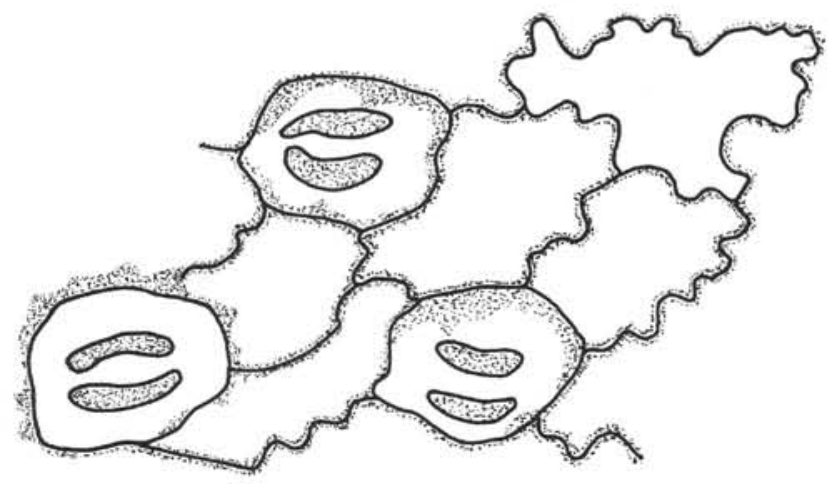

Figure 12. Cycadeoid cuticle, specimen PB127, X 325.

a thickened cuticular strip on the curved surface adjacent the guard cell along the outermost wall adjacent the epidermal cells (Plate 2 , Figure 25). There are on the cuticle rare circular thickenings, $25 \mu \mathrm{m}$ in diameter, which may represent the remains of rather large hollow trichomes (Plate 2, Figure 25).

Very clearly, this fragment belongs to a member of the Cycadeoidaceae, but without further data on the overall morphology of the leaf, it is impossible to align it with any known genus of that family.

\section{Cycadeoid Type B}

(Plate 2, Figure 26; Text-Figure 13)

Description: A single near-apical leaflet fragment, $3.2 \mathrm{~mm}$ long by $1.2 \mathrm{~mm}$ wide. This fragment consists of unseparated upper and lower cuticles. The stomata are confined to one surface, presumably the lower. Upper cuticle is composed of uniformly, elongate rectangular cells up to six times as long as broad, arranged in rows parallel the long axis of the leaflet. Cells nearer the margin are more narrow than the median cells (Plate 2, Figure 26). Each cell is outlined by its thin, very regularly sinuous anticlinal walls (Plate 2, Figure 26).

The distribution of the stomata on the lower surface is obscured, but it seems to be irregular with most stomata concentrated in the central portion of the leaflet. The stomata are broadly elliptical to circular usually about $40 \mu \mathrm{m}$ along the long axis (Figure 13). Subsidiary cells are semicircular and thicker and the periclinal surface than the surrounding epidermal cells. The guard cells are somewhat thinner, possibly slightly sunken beneath the level of the subsidiary cells.

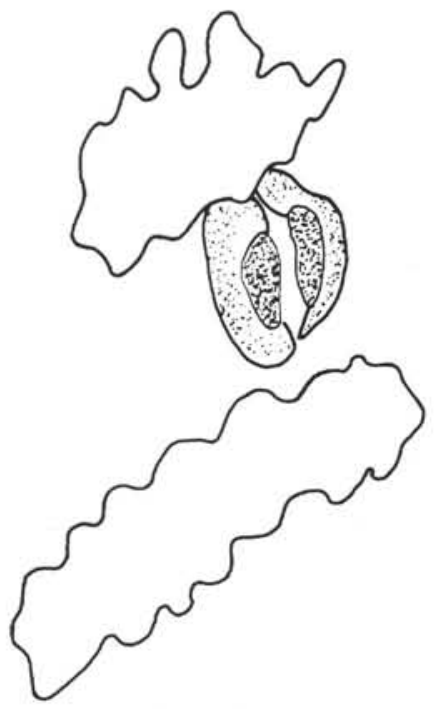

Figure 13. Cycadeoid cuticle lower surface, specimen $P B$ $128, \times 375$. 


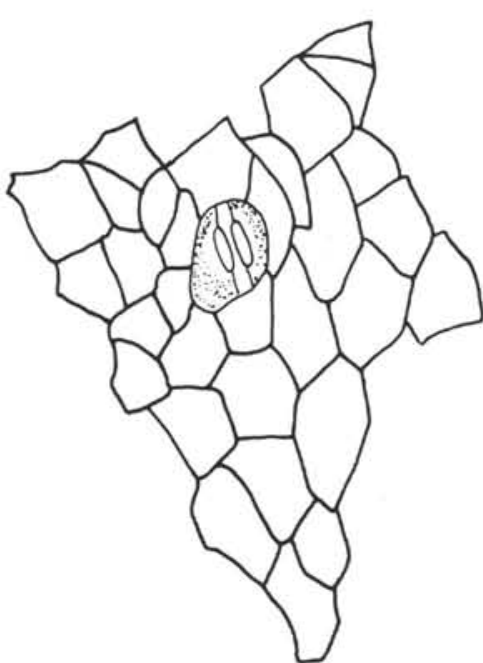

Figure 14. Cycadeoid cuticle, specimen PB126, X 200.

Papillae or trichomes occur in fair numbers on the cells of the central area of the upper cuticle (Plate 2, Figure 26).

\section{Cycadeoid Type C}

(Plate 2, Figure 24; Text-Figure 14)

Description: This specimen is only classified with the Cycadeoidaceae on the basis of its syndetocheilic stomata. It is a single fragment composed of isodiametric, polygonal cells with thin straight walls (Figure 14; Plate 2, Figure 24). At wide intervals, there are stomata with irregularly oriented pores. Basically, the stomata apparatus is similar to that of Cycadeoid Type A with semicircular to rectangular subsidiary cells and evenly cutinized periclinal walls (Figure 14; Plate 2, Figure 24). Each guard cell has a cutinized outer wall. The subsidiary cells measure up to $60 \mu \mathrm{m}$ across with the cutinized portion of the guard cells about $25 \mu \mathrm{m}$ in length. Some stomata seem to be surrounded by a partially complete ring of slightly modified epidermal cells which are elongate tangential to the subsidiary cells (Plate 2, Figure 24).

The scarcity of stomata and the straight-walled epidermal cells of this type of cuticle bear a close resemblance to those reported to occur on the adaxial cuticles of several species of Cycadolepis from the Ticó Flora (Menendez, 1966). Without a complete specimen, it cannot be determined to that genus. It would be reasonable to expect that at least some of the cuticular fragments recovered from sediments containing cycadeoid leaves would belong to Cycadolepis, the genus to which scale leaves or bracts of the cycadeoids are assigned. These bracts are frequently found in greater numbers and variety than large vegetative leaves in Mesozoic floras where cycadeoids occur.

\section{ECOLOGY AND FLORAL AFFINITY}

Four floras which are considered to be of similar age and to have been located near what was then Site 361 are known from land-based collections; the gross morphology of the plants comprising these floras is of prime importance in their individual generic diagnoses. Since only one of the nine types of cuticle from the Site 361 cores is attached to its stem, allowing thus a generic assignment, no species by species comparisons are attempted between Site 361 and the four land-based floras.

Among these floras exist overall similarities of a more general floristic nature, chiefly the predominance of conifers and cycadeoids. This suggests that there were only minor differences in the appearance of the plant communities which the presently known fossils represent. All of the floras were dominated by conifers, usually the small scale leaved type, represented by Brachyphyllum and Athrotaxites in the South American and the South African (Uitenhage) flora, or Pagiophyllum and three other types in the Site 361 flora. Conifers of the long needle leaved type, which occur in many other Cretaceous floras, are somewhat rarer. The broad leaved type, represented by Podozamites, is also of secondary importance in numbers. The cycadeoids are well represented in all of the floras by many well known genera. Ginkgophytes are unknown from the two South African floras but are more abundant in South America, i.e., Ticó, and in the Graham Land flora of Antarctica. Although no ferns have been recovered from the Site 361 cores, a number of common genera are known from the other four floras. Especially important seems to be Onychiopsis psilotoides which occurs in each of them and is a fairly widespread genus of Wealden age (Barnard, 1973). None of the genera included in the Tico flora, the best known of the four, can be definitely shown to occur at Site 361. The overall make-up of the Ticó and Site 361 floras is, however, thought to be significant. The relative abundance of coniferous and cycadeoid leaves and the occurrence of the leaf fragments (Gymnosperm Type B) with resemblance to the pteridosperms reported by Archangelsky (1963) are indicative of a similar type of floral development in the Argentine and Site 361 floras in the Lower Cretaceous.

The Lower Cretaceous Uitenhage flora from the Algoa Bay area of South Africa has, as far as known, a similar diversity of plant remains to the Tico and Site 361 floras (Seward, 1903). Cycadeoids are represented in the Uitenhage flora by four species of Zamites and one of Cycadolepsis and the conifers by one species each of Brachyphyllum and Araucarites (Seward, 1903). Since none of the specimens from the Uitenhage is preserved with sufficient cuticle for study, it is impossible to correlate exactly these species with either the Tico or Site 361 floras. In the Uitenhage several species of fern-like foliage exist which, if the cuticle were known, might prove to be related to several of the Ticó pteridosperms.

Halle's (1913a, b) Tierra del Fuego and the Lago San Martin floras of Argentina have been correlated with the Tico flora, and they resemble the Site 361 flora in the dominating presence of conifers and cycadeoids. Although no decisive age correlation is possible because the Site 361 material is too fragmentary to classify precisely, the resemblance between the diversified conifer and cycadeoid elements indicates a broadly similar age and stage of floristic development.

It seems that in the Upper Jurassic and Lower Cretaceous there existed around the opening South Atlantic five broadly similar floras in what are now three distinctly different floristic areas, South America, South Africa, and Antarctica. This, based on relative proportions of the major plant groups of the time, indicates a similar type of environment and no great latitudinal separation. As can be seen in the paleolatitude map (Figure 1), in the mid-Cretaceous, the five floras considered here surround the newly created South Atlantic. In even earlier times, their geographic separation would have been somewhat less (Smith et 
al., 1973). All five floras have a predominance of gymnosperms, and it may be significant that the angiosperms, which are thought by some authors to have arisen in Western Gondwana by the Early Cretaceous, had not yet penetrated this rather widespread area (Raven and Axelrod, 1974). It is still, of course, a matter of opinion as to where and when the angiosperms first evolved, but it is curious that they should appear so rapidly in the Aptian-Albian strata of the Northern Hemisphere not much later than these Southern Hemisphere floras, when as yet there is no evidence to indicate their occurrence, or that of some clearly defined ancestor, in the area much closer to their supposed point of origin (Barnard, 1973).

The conifer Pagiophyllum which occurs at Site 361 has been referred at other localities to the Family Cheirolepidaceae, which has been shown to produce Classopolis pollen (Archangelsky, 1968). These Classopolis bearing conifers have been interpreted as having occupied the seaward margins of deltas (Hughes, 1973). This, in turn, would indicate that the Site 361 megafossil flora was a near-shore plant community dominated by conifers and cycadeoids, and the remains were probably not transported far from their point of growth. The wood fragments which were recovered from the cores were almost entirely small pieces with a very rounded profile. They are similar in shape to the small pieces of wood or other plant fragments, frequently worn round, which are found at the high tide lines on present-day beaches.

In summary, the Site 361 flora resembles, in its overall appearance, other Jurassic-Lower Cretaceous floras which grew around the basin of the newly opened South Atlantic and is most likely to have been a nearshore plant community dominated by conifers and cycadeoids probably growing not far from the site at which they were recovered during the drilling.

\section{REFERENCES}

Adams, A.W., 1951. Pagiophyllum gracillimum sp. nov., a conifer from the Jurassic of Yorkshire: Ann. Mag. Nat. Hist. Ser. 12, v. 4, p. 1132.
Archangelsky, S., 1963. A new Mesozoic flora from Ticó, Santa Cruz Province, Argentina: Brit. Mus. (Nat. Hist.) Bull. Geol., v. 8, p. 47.

1965. Fossil Ginkgoales from the Ticó Flora Santa Cruz Province, Argentina: Brit. Mus. (Nat. Hist.) Bull. Geol., v. 10, p. 121. 1966. New Gymnosperms from the Tico Flora, Santa Cruz Province, Argentina: Brit. Mus. (Nat. Hist.) Bull. Geol, v. 13, p. 259.

1968. On the genus Tomaxellia (Coniferae) from the lower Cretaceous of Patagonia (Argentina) and its male and female cones: J. Linn. Soc. (London) Bot., v. 61, p. 153 .

Ash, S., 1970. Pagiophyllum simpsonii, a new conifer from the Chinle Formation, Upper Triassic of Arizona: J. Paleontol., v. 44, p. 945.

Barnard, P.D.W., 1968. A new species of Masculostrobus Seward producing Classopolis pollen from the Jurassic of Iran: J. Linn. Soc. (London) Bot., v. 61, p. 167.

1973. Mesozoic floras. In Hughes, N.F. (Ed.), Organisms and continents through time: Spec. Papers in Palaeont. of the Palaeont. Assoc. London, v. 12, p. 175.

Halle, T.G., 1913a. Mesozoic plant bearing deposits in Patagonia and Tierra del Fuego and their floras: Kungl. Svenska Vet.-Akad. Handl., v. 51, p. 1. 1913b. The Mesozoic flora of Graham Land: Wiss. Engeb. Schwed. Sudpol. Exped., v. 3, p. 1.

Hughes, N.F., 1973. Mesozoic and Tertiary distributions and problems of land plant evolution. In Hughes, N.F. (Ed.). Organisms and continents through time: Spec. Papers in Palaeont. of the Palaeont. Assoc. London, v. 12, p. 188.

Kendall, M., 1948. On six species of Pagiophyllum from the Jurassic of Yorkshire and Southern England. Ann. Mag. Hist. Ser. 12, v. 1, p. 73.

Menendez, C.A., 1966. Fossil Bennettitales from the Tico flora, Santa Cruz Province, Argentina: Brit. Mus. (Nat. Hist.) Bull. Beol., v. 12, p. 1.

Raven, P.H. and Axelrod, D.I., 1974. Angiosperm biogeography and post continental movements: Ann. Missouri Bot. Gard., v. 61, p. 539.

Seward, A.C., 1903. Fossil floras of Cape Colony: Ann. South African Mus., v. 4, p. 1.

Smith, A.G., Briden, J.C., and Drewry, G.E., 1973. Phanerozoic world maps. In Hughes, N.F. (Ed.), Organisms and continents through time: Spec. Papers in Palaeont. of the Palaeont. Assoc. London, v. 12, p. 1. 



\section{PLATE 1}

Figures 15-19 Pagiophyllum maritimum sp. nov.

15. Pagiophyllum maritimum, holotype, PBI25, $\times 20$.

16. Apical and marginal cells, PB134, $\times 150$.

17. Stomata and epidermal cells, PBI $34, \times 150$.

18. Single stoma showing guard cells, PBI35. $\times 260$.

19. Elongate stomata and epidermal cells from leaf base, PB135, $\times 150$.

20. Gymnosperm cuticle with two rows of transversely oriented stomata and papillate cells. PB131, 190.

\section{PLATE 2}

Figures 21-26 Gymnosperm cuticles.

21. Papillate conifer stomata and epidermal cells, PB129, $\times 100$.

22. Papillate conifer stomata and median basal band of papillate epidermal cells, PB $32, \times 75$.

23. Papillate gymnosperm with stomatal rows and double encircling cells, PB130, $\times 200$.

24. Cycadeoid cuticle with straight walled cells and single stoma, PB126, $\times 250$.

25. Cycadeoid with transversely oriented stomatal pores; note trichome base slightly above center, PB127, $\times 225$.

26. Cycadeoid cuticle, upper surface with narrow marginal cells, PB128, $\times 200$.

(see p. 686) 
PLATE 1

PLATE 2
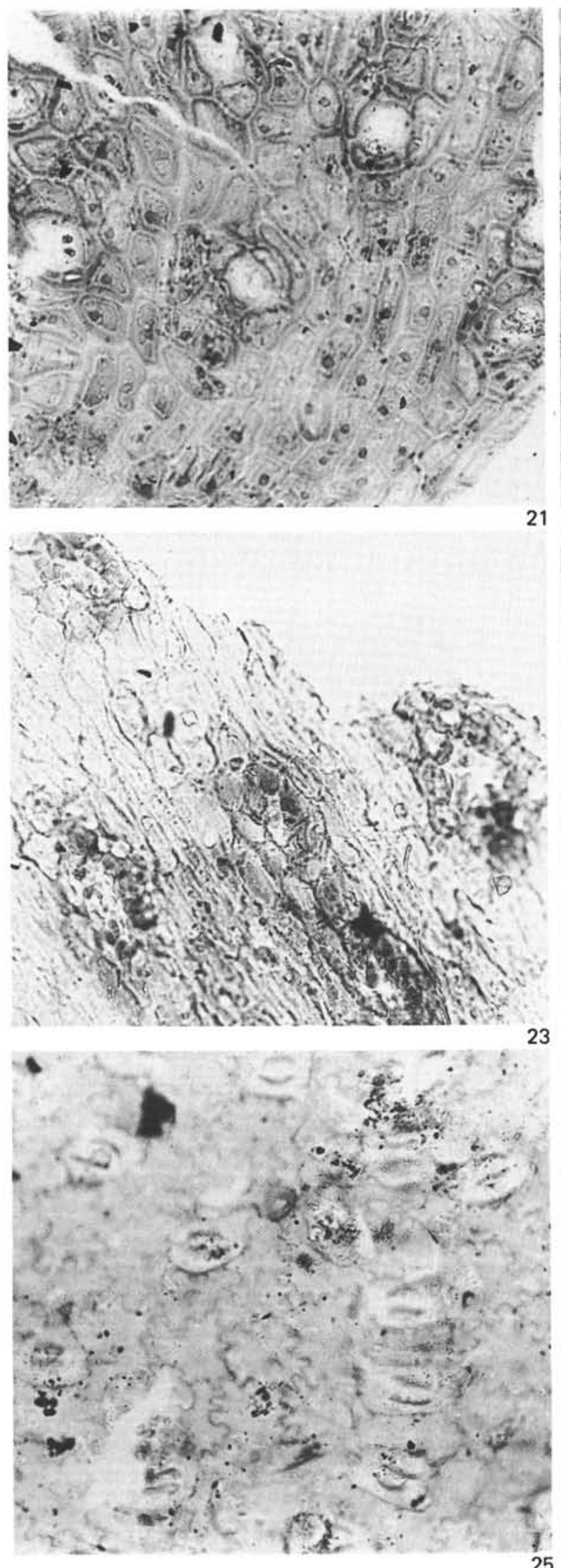
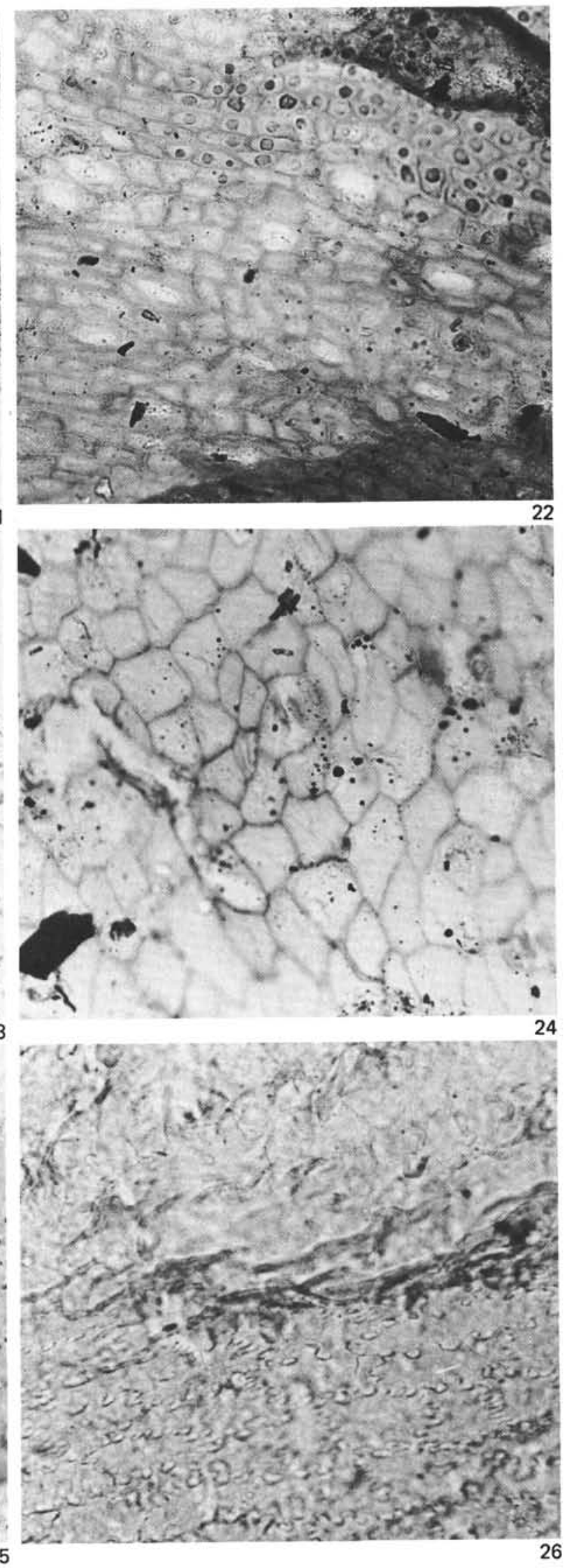